\title{
Comparison of Metal Content of Coffee Samples Grown in Different Countries by Inductively Coupled Plasma Optical Emission Spectroscopy
}

\author{
Sabah H. Al-Jaf ${ }^{1 *}$, Sinan Saydam ${ }^{2}$ \\ ${ }^{1}$ Garmian University, College of Education, Department of Chemistry, sulaymaneyah, Iraq \\ ${ }^{2}$ Firat University, Faculty of Science, Department of Chemistry, 23200 Elazig, Turkey \\ *sabah.hassan@garmian.edu.krd
}

Received: 20 June 2018

Accepted: 14 February 2019

DOI: $10.18466 /$ cbayarfbe. 434988

\begin{abstract}
Coffee is the one of the most consumed beverage across the world. Therefore, it has a commercial value and social importance. Coffee consumption continues to increase due to its physiological effects, its pleasant taste, aroma and many health benefits. In this study six different coffee samples from six different countries were analyzed for determining concentration of 17 elements by using inductively coupled plasma optical emission spectroscopy (ICP-OES). According to the obtained results, elements were classified into three groups of macro, micro, and trace elements according to their concentration; among the macro elements potassium concentration were highest $(10508 \mathrm{mg} / \mathrm{L})$ average concentration in all samples; whereas the average concentration of calcium were found to be lowest $(296.33 \mathrm{mg} / \mathrm{L})$ in this group. Micro elements showed the concentration order of: $\mathrm{Sr}>\mathrm{Mn}>\mathrm{Fe}>\mathrm{Al}>\mathrm{Ba}>\mathrm{Cu}>\mathrm{Zn}$ by concentration of 12.66, 12.28, $6.35,3.81,3.79,3.05$, and $2.61 \mathrm{mg} / \mathrm{L}$ respectively. Concentrations of selenium were higher than all other elements in the group of trace elements by average concentration of $0.61 \mathrm{mg} / \mathrm{L}$. The results obtained in this study showed there are significant differences between different elemental content of different coffee samples grown in different region.
\end{abstract}

Keywords: Coffee, coffee sample, elements, Trace element, analysis, Inductively Coupled Plasma Optical Emission Spectroscopy (ICP-OES).

\section{Introduction}

Coffee is one of the most consumed drinks in world that it is ranked after petroleum as the second most traded global commodity [1] and it is exported to more than 167 different countries with more than 9.0 million ton annual consumption in recent years [8]. Coffee is an agricultural product that plays an important role in the international trade [2].

Coffee is an important plantation crop which belongs to the Rubiaceae and genera Coffea family; they are shrubs or small trees (Figure 1). Usually the coffee plant is a woody perennial tree that is growing at region of higher altitudes [5]. Coffea arabica (Arabica coffee) and Coffea canephora (Robusta coffee) are the most important types among 70 different species of genera Coffea that have been reported. There is difference in caffeine contents, taste, and appearance between these two varieties. Arabica coffee is favored by a hedonic trend of consumers as compared to Robusta coffee [5].

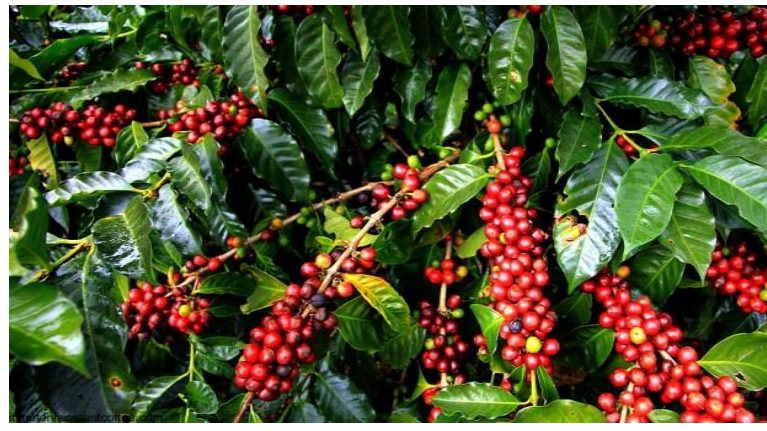

Figure 1. Arabica Coffee Plants.

It is recognized that the coffee beverage is a rich source of elements, including those that are essential for the human health, in addition to non-essential elements and even toxic to human take up from a polluted soil [2]. Coffee contains various elements such as $\mathrm{Na}, \mathrm{B}, \mathrm{Mg}, \mathrm{Fe}$, $\mathrm{Ca}, \mathrm{K}$ and many other elements. These elements have various effects on human health such as $\mathrm{Na}$ helps to regulate the body's water balance. [3, 9]. $\mathrm{Mg}$ is a cofactor of enzyme systems [10]. Fe is an important for normal human physiology and for most life forms [12]. 
Therefore, the determination of total concentrations of elements in coffee enables to assess its nutritive quality and also helps to judge its possible ill-effect that may cause to the human health [2].

Information available in literature about the levels of the trace elements present in coffee beans from different origins is limited, different analytical techniques in a number of studies have been used for the determination of some elements (major, minor and toxic element) in different types of roasted, and green coffee beans in different countries around the world [6].

Concentration of 14 elements $(\mathrm{Ca}, \mathrm{Cd}, \mathrm{Pb}, \mathrm{Mn}, \mathrm{Fe}, \mathrm{Na}$, $\mathrm{K}, \mathrm{P}, \mathrm{Mg}, \mathrm{Cr}, \mathrm{Ni}, \mathrm{Co}, \mathrm{Cu}, \mathrm{Zn}$ ) in coffee were determined by Grembecka et al. [7]. Oliveira et al. determined amount of 9 elements $(\mathrm{Mg}, \mathrm{Na}, \mathrm{Fe}, \mathrm{Ca}, \mathrm{K}, \mathrm{P}, \mathrm{Cr}, \mathrm{Ni}$, and $\mathrm{Mn}$ ) in soluble powdered instant coffees [4]. The levels of some bioactive amines, five elements $(\mathrm{K}, \mathrm{Na}, \mathrm{Mg}, \mathrm{Zn}$, and $\mathrm{Mn}$ ), total ash content, $\mathrm{pH}$ values, and total dry matter content in ground coffee and brewed Turkish coffees were investigated by Ozdestan [15]. Stelmach, et al. measured total concentrations of $\mathrm{Mn}, \mathrm{Cu}, \mathrm{Mg}, \mathrm{Fe}$, and $\mathrm{Ca}$, in the green coffee infusions by using high resolutioncontinuum source flame atomic absorption spectrometry [11]. Ashu et al. determined the concentrations of 11 elements ( $\mathrm{Cd}, \mathrm{Cu}, \mathrm{Co}, \mathrm{Ca}, \mathrm{Mn}, \mathrm{K}, \mathrm{Fe}, \mathrm{Pb}, \mathrm{Na}, \mathrm{Zn}, \mathrm{Mg}$ ) in three different brands of roasted coffee powders from Ethiopia and their infusions by flame atomic absorption spectrometry (FAAS) [6]. Szymczycha et al. compared six procedures for sample preparation, for determining the amount of $(\mathrm{Ca}, \mathrm{Pb}, \mathrm{Mg}, \mathrm{Ba}, \mathrm{Ni}, \mathrm{Fe}, \mathrm{Cd}, \mathrm{Mn}, \mathrm{P}, \mathrm{Cr}, \mathrm{Sr}, \mathrm{Zn}$ and $\mathrm{Cu}$ ) in slim instant coffees by inductively coupled plasma optical emission spectrometry (ICP-OES), they established that the extraction with aqua regia provides better results as compared to other digestion procedures [16].

This study was aimed to determine the concentrations of some major, minor and trace elements in six different coffee samples from six different origins (Brazil, Colombia, Ethiopia, Guatemala, Kenya, and Yemen) where the coffee plants grown. The coffee samples were analyzed for seventeen elements ( $\mathrm{Al}, \mathrm{As}, \mathrm{Ba}, \mathrm{Ca}, \mathrm{Cr}, \mathrm{Cu}, \mathrm{Fe}, \mathrm{K}, \mathrm{Mn}$, $\mathrm{Na}, \mathrm{Ni}, \mathrm{P}, \mathrm{Se}, \mathrm{Sn}, \mathrm{Sr}, \mathrm{Zn}$, and $\mathrm{Mg}$ ) by using inductively coupled plasma optical emission spectroscopy (ICP-OES).

\section{Materials and Methods \\ 2.1. Chemical reagents}

All of the reagents that have been used in present study were of the analytical grades. All of the prepared aqueous solutions prepared by deionized water. Concentrated $\mathrm{HNO}_{3}$ and $\mathrm{HCl}$ (Merck, Darmstadt- Germany) solutions were used for the digesting the coffee samples. All of the standard solutions prepared by diluting multi-element $(1000 \mu \mathrm{g} / \mathrm{mL})$ ICP standard (Bernd Kraft der standard).
Deionized water was obtained from (Thermos - Germany) water purification system. All glassware and plastic bottles that used in this work were washed by $10 \%(\mathrm{~m} / \mathrm{v}) \mathrm{HNO}_{3}$ and rinsed many times with deionized water.

\subsection{Coffee samples}

Six coffee samples from six different origins (Brazil (CB), Colombia (CC), Ethiopia (CE), Guatemala (CG), Kenya (CK), and Yemen (CY)) were selected for the analysis. All coffee samples were purchased from local markets of Turkey.

\subsection{Sample preparation}

Digestion of the coffee samples were done by taking $0.500 \mathrm{~g}$ of each coffee sample into a beaker and $2 \mathrm{ml}$ of aquaregia $\left(1: 3 \mathrm{HNO}_{3}: \mathrm{HCl}\right)$ were added then the resulting mixture were sonicated in ultra-sonic bath for 1 hour, after that 10.0 $\mathrm{ml}$ of deionized water were added, filtrated to remove any undissolved particle then diluted to $25 \mathrm{ml}$ with deionized water.

\subsection{Operating conditions for ICP - OES instrument}

An ICP - OES instrument (Spectro-Arcos - Germany) used for the analysis of elements under study. The conditions of the operation of ICP - OES instrument were as follows: 1400 watts of a RF power, $13 \mathrm{~L} / \mathrm{min}$ coolant flow rate, 1 $\mathrm{L} / \mathrm{min}$ auxiliary flow, $0.83 \mathrm{~L} / \mathrm{min}$ nebulizer flow and 1.2 $\mathrm{mL} / \mathrm{min}$ of sample uptake rate. Measurements of all of the elements were done in triplicate. Table 1 shows the characteristics data of the calibration curves of elements using ICP-OES.

\section{Results and Discussion 3.1. Analysis Results}

In this study, concentration of 17 elements ( $\mathrm{Al}, \mathrm{As}, \mathrm{Ba}, \mathrm{Ca}$, $\mathrm{Cr}, \mathrm{Cu}, \mathrm{Fe}, \mathrm{K}, \mathrm{Mn}, \mathrm{Na}, \mathrm{Ni}, \mathrm{P}, \mathrm{Se}, \mathrm{Sr}, \mathrm{Sn}, \mathrm{Zn}$ and $\mathrm{Mg}$ ) were determined in coffee samples by inductively coupled plasma optical emission spectroscopy (ICP-OES). According to the obtained results in this study the measured elements can be classified into three main group, due to their concentration, the first group will be named as macro or essential element because their concentrations are too high in coffee as compared to other elements and include five elements which are $(\mathrm{Ca}, \mathrm{K}, \mathrm{Na}, \mathrm{P}$ and $\mathrm{Mg})$, the concentration trend of macro elements were fund to be as follows: $\mathrm{K}>\mathrm{Mg}>\mathrm{Na}>\mathrm{P}>\mathrm{Ca}$ by concentration range of 9360-11635, 420.63-500.77, 240.73-353.38, 251.07342.38, and 243.93-334.73 mg/L for K, Mg, Na, P, and Ca respectively.

Coffee beverages are one of the important sources of some micro elements like $\mathrm{Mn}, \mathrm{Zn}$ and $\mathrm{Cu}$ which are necessary for the metabolic processes in human. Second group of elements determined in coffee in present study were some 
micro elements and including elements like $(\mathrm{Zn}, \mathrm{Al}, \mathrm{Cu}$, $\mathrm{Ba}, \mathrm{Sr}, \mathrm{Fe}$, and $\mathrm{Mn}$ ).

The order of mean concentrations of the micro elements in all analyzed coffee samples was found to be: $\mathrm{Sr}>\mathrm{Mn}>\mathrm{Fe}>$ $\mathrm{Ba}>\mathrm{Al}>\mathrm{Cu}>\mathrm{Zn}$ by the concentration of 9.583-16.783, 7.283-14.617, 5.1667-8.1, 1.3-6.45, 2.95-4.5833, 2.853.33, and 1.9-3.25 mg/L for $\mathrm{Sr}, \mathrm{Mn}, \mathrm{Fe}, \mathrm{Ba}, \mathrm{Al}, \mathrm{Cu}$, and $\mathrm{Zn}$ respectively.

The third and final group of elements determined is trace elements in which coffee samples contain some essential trace elements like $\mathrm{Ni}, \mathrm{Cr}$, and $\mathrm{Se}$ which are essential nutrients that are cofactors for the metabolism and some other biological processes. Trace elements like (Ni, As, Se $\mathrm{Cr}$, and $\mathrm{Sn}$ ) were determined in coffee samples in present study, among trace elements; $\mathrm{Se}$ is the highest concentration by $0.45-0.73 \mathrm{mg} / \mathrm{L}$ followed by $\mathrm{Ni}, \mathrm{Cr}, \mathrm{Sn}$ and As by concentration of $0.01667-0.36667,0.05-0.3$, $0.06667-0.15$, and $0.05-0.16667 \mathrm{mg} / \mathrm{L}$ for $\mathrm{Ni}, \mathrm{Cr}, \mathrm{Sn}$, and As respectively. The analysis results of the coffee samples for all the elements studied are given in table 2 as $\mathrm{mg} / \mathrm{L}$.

Table 1. Characteristics data of the calibration curves of elements using ICP-OES.

\begin{tabular}{|l|l|l|l|l|l|}
\hline Elements & Equation & $\mathbf{R}^{\mathbf{2}}$ & Wave length(nm) & $\begin{array}{l}\text { Linear range } \\
\left(\mathbf{m g} . \mathbf{L}^{-\mathbf{1}}\right)\end{array}$ & DL $\left(\mathbf{m g . L ^ { - 1 }}\right)$ \\
\hline $\mathbf{A l}$ & $\mathrm{y}=3.2113 \mathrm{x}+0.1235$ & 1.00000 & 176.641 & $0.00355-24$ & 0.00355 \\
\hline $\mathbf{A s}$ & $\mathrm{y}=9.0001 \mathrm{x}+0.0804$ & 0.99994 & 189.042 & $0.00264-2.4$ & 0.00264 \\
\hline $\mathbf{B a}$ & $\mathrm{y}=1055.1 \mathrm{x}+16.513$ & 0.99994 & 455.404 & $0.000441-2.4$ & 0.000441 \\
\hline $\mathbf{C a}$ & $\mathrm{y}=0.0767 \mathrm{x}+0.0524$ & 0.99998 & 315.887 & $0.00419-600$ & 0.00419 \\
\hline $\mathbf{C r}$ & $\mathrm{y}=76.47 \mathrm{x}+0.6904$ & 0.99993 & 267.716 & $0.000457-2.4$ & 0.000457 \\
\hline $\mathbf{C u}$ & $\mathrm{y}=169.69 \mathrm{x}+2.0525$ & 0.99995 & 324.754 & $0.00126-2.4$ & 0.00126 \\
\hline $\mathbf{F e}$ & $\mathrm{y}=0.1165 \mathrm{x}-0.0181$ & 0.99982 & 259.941 & $0.00145-60$ & 0.00145 \\
\hline $\mathbf{K}$ & $\mathrm{y}=5.9976 \mathrm{x}+0.7163$ & 0.99957 & 766.491 & $0.0316-24$ & 0.0316 \\
\hline $\mathbf{M n}$ & $\mathrm{y}=0.5213 \mathrm{x}-0.0009$ & 0.99997 & 257.611 & $0.000226-6$ & 0.000226 \\
\hline $\mathbf{N a}$ & $\mathrm{y} 0.053 \mathrm{x}+0.0606$ & 0.99987 & 589.592 & $0.0552-240$ & 0.0552 \\
\hline $\mathbf{N i}$ & $\mathrm{y}=68.03 \mathrm{x}+0.4872$ & 0.99996 & 231.604 & $0.000974-2.4$ & 0.000974 \\
\hline $\mathbf{P}$ & $\mathrm{y}=6.7779 \mathrm{x}-0.5846$ & 0.99998 & 177.495 & $0.00245-60$ & 0.00245 \\
\hline $\mathbf{S e}$ & $\mathrm{y}=4.9216 \mathrm{x}+0.2345$ & 0.99976 & 196.090 & $0.0087-2.4$ & 0.0087 \\
\hline $\mathbf{S r}$ & $\mathrm{y}=6.6695 \mathrm{x}+0.0972$ & 0.99978 & 407.771 & $9.63 \mathrm{e}-005-2.4$ & $9.63 \mathrm{e}-005$ \\
\hline $\mathbf{S n}$ & $\mathrm{y}=20.731 \mathrm{x}+0.1671$ & 0.999998 & 189.991 & $0.00194-2.4$ & 0.00194 \\
\hline $\mathbf{Z n}$ & $\mathrm{y}=0.2307 \mathrm{x}+0.0011$ & 1.00000 & 213.856 & $0.000633-24$ & 0.000633 \\
\hline $\mathbf{M g}$ & $\mathrm{y}=0.0081 \mathrm{x}-0.0028$ & 0.99999 & 279.079 & $0.00576-240$ & 0.00576 \\
\hline
\end{tabular}

\subsection{Comparison with Previous Studies}

Generally the results that obtained in this study showed good agreement with most of the reported values except for some of the macro elements in which the results obtained here is slightly lower than previous reported values. Concentrations of calcium, potassium, sodium, magnesium, iron, and nickel in coffee samples obtained in present study were lower than the reported values by Krivan et al. 1993 [13], Santos et al. 2008 [17], Martin et al. 1999 [18], and Sussela et al. 2001 [20]. Concentrations of sodium in present study were higher than the reported values by Tagliaferro et al. 2007 [19], and Anderson and Smith 2002 [14].Amount of phosphorus (P), aluminum $(\mathrm{Al})$, barium $(\mathrm{Ba})$, copper $(\mathrm{Cu})$, manganese $(\mathrm{Mn})$, zinc $(\mathrm{Zn})$, arsenic (As), chromium ( $\mathrm{Cr}$ ), and selenium ( $\mathrm{Se}$ ) found in coffee samples in present study were in good agreements with the values reported previously, while concentration of strontium ( $\mathrm{Sr}$ ) obtained in present study were slightly higher than values that reported by Santos et al. 2008 [17], martin et al. 1999 [18], and Sussela et al. 2001 [20]. 
Table 2. Concentrations (mg/L) of elements (mean \pm standard deviation) in six coffee samples.

\begin{tabular}{|l|l|l|l|l|l|l|}
\hline & \multicolumn{1}{|c}{ CB } & \multicolumn{1}{c}{ CC } & \multicolumn{1}{c|}{ CE } & \multicolumn{1}{c|}{ CG } & \multicolumn{1}{c|}{ CK } & \multicolumn{1}{c|}{ CY } \\
\hline $\mathrm{Al}$ & $3.633 \pm 0.160$ & $4.250 \pm 0.050$ & $2.950 \pm 0.100$ & $2.950 \pm 0.132$ & $4.500 \pm 0.450$ & $4.583 \pm 0.104$ \\
\hline $\mathrm{As}$ & $0.166 \pm 0.076$ & $0.116 \pm 0.125$ & $0.050 \pm 0.043$ & $0.050 \pm 0.000$ & $0.083 \pm 0.028$ & $0.083 \pm 0.057$ \\
\hline $\mathrm{Ba}$ & $0.933 \pm 0.028$ & $6.916 \pm 0.028$ & $3.200 \pm 0.050$ & $6.450 \pm 0.050$ & $3.983 \pm 0.057$ & $1.300 \pm 0.000$ \\
\hline $\mathrm{Ca}$ & $283.82 \pm 14.07$ & $306.87 \pm 17.25$ & $243.93 \pm 9.93$ & $298.03 \pm 10.97$ & $310.88 \pm 14.54$ & $334.73 \pm 9.70$ \\
\hline $\mathrm{Cr}$ & $0.066 \pm 0.076$ & $0.300 \pm 0.100$ & $0.116 \pm 0.057$ & $0.050 \pm 0.025$ & $0.083 \pm 0.028$ & $0.150 \pm 0.050$ \\
\hline $\mathrm{Cu}$ & $2.850 \pm 0.100$ & $3.266 \pm 0.202$ & $2.916 \pm 0.076$ & $2.966 \pm 0.104$ & $3.016 \pm 0.125$ & $3.333 \pm 0.076$ \\
\hline $\mathrm{Fe}$ & $5.166 \pm 0.650$ & $7.033 \pm 0.828$ & $5.183 \pm 0.664$ & $5.533 \pm 0.505$ & $7.100 \pm 0.785$ & $8.100 \pm 0.427$ \\
\hline $\mathrm{K}$ & $10357 \pm 21$ & $10012 \pm 161$ & $10723 \pm 68$ & $11635 \pm 154$ & $9360 \pm 83$ & $10964 \pm 216$ \\
\hline $\mathrm{Mn}$ & $11.667 \pm 0.562$ & $13.483 \pm 0.825$ & $7.283 \pm 0.404$ & $12.650 \pm 0.541$ & $14.617 \pm 0.709$ & $14.000 \pm 0.436$ \\
\hline $\mathrm{Na}$ & $302.82 \pm 3.87$ & $293.45 \pm 1.89$ & $240.73 \pm 4.58$ & $333.42 \pm 2.60$ & $294.57 \pm 1.80$ & $353.38 \pm 0.65$ \\
\hline $\mathrm{Ni}$ & $0.150 \pm 0.050$ & $0.333 \pm 0.076$ & $<\mathrm{DL}$ & $0.016 \pm 0.028$ & $0.216 \pm 0.028$ & $0.366 \pm 0.028$ \\
\hline $\mathrm{P}$ & $295.27 \pm 12.82$ & $299.73 \pm 10.38$ & $325.98 \pm 14.84$ & $251.07 \pm 5.09$ & $342.38 \pm 11.98$ & $283.67 \pm 6.23$ \\
\hline $\mathrm{Se}$ & $0.616 \pm 0.125$ & $0.700 \pm 0.229$ & $0.533 \pm 0.125$ & $0.450 \pm 0.132$ & $0.733 \pm 0.057$ & $0.633 \pm 0.160$ \\
\hline $\mathrm{Sn}$ & $0.066 \pm 0.076$ & $0.133 \pm 0.763$ & $0.083 \pm 0.028$ & $0.100 \pm 0.050$ & $0.083 \pm 0.057$ & $0.150 \pm 0.000$ \\
\hline $\mathrm{Sr}$ & $9.583 \pm 0.029$ & $16.783 \pm 0.252$ & $9.733 \pm 0.126$ & $15.767 \pm 0.104$ & $12.967 \pm 0.076$ & $11.183 \pm 0.208$ \\
\hline $\mathrm{Zn}$ & $2.266 \pm 0.175$ & $2.816 \pm 0.175$ & $1.900 \pm 0.132$ & $2.416 \pm 0.104$ & $3.250 \pm 0.180$ & $3.050 \pm 0.132$ \\
\hline $\mathrm{Mg}$ & $463.48 \pm 18.64$ & $455.35 \pm 25.14$ & $420.63 \pm 21.24$ & $447.75 \pm 16.50$ & $500.77 \pm 24.18$ & $493.60 \pm 14.08$ \\
\hline
\end{tabular}

Comparison of the results in present study with some previous studies for determination of macro, micro and trace elements are showed in table 3, 4 and 5 respectively.

Table 3. Comparison of the results of present study with previous studies for macro elements.

\begin{tabular}{|c|c|c|c|c|c|c|c|}
\hline \multirow[b]{2}{*}{ element } & \multicolumn{7}{|c|}{ Concentration ranges in $\mathrm{mg} / \mathrm{L}$} \\
\hline & $\begin{array}{l}\text { Present } \\
\text { study }\end{array}$ & $\begin{array}{c}\text { Krivan et } \\
\text { al. } 1993\end{array}$ & $\begin{array}{l}\text { Santos et } \\
\text { al. } 2008\end{array}$ & $\begin{array}{l}\text { Martin et } \\
\text { al. } 1999\end{array}$ & $\begin{array}{l}\text { Sussela et } \\
\text { al. } 2001\end{array}$ & $\begin{array}{l}\text { Tagliaferro } \\
\text { et al. } 2007\end{array}$ & $\begin{array}{c}\text { Anderson } \\
\text { and Smith } \\
2002\end{array}$ \\
\hline $\mathrm{Ca}$ & $243-334$ & $869-1171$ & $1227-1437$ & $870-1170$ & $490-971$ & $1150-1580$ & $934-1234$ \\
\hline $\mathrm{K}$ & $\begin{array}{l}9360- \\
11635\end{array}$ & $\begin{array}{l}14000- \\
16000\end{array}$ & $\begin{array}{l}19435- \\
20111\end{array}$ & $\begin{array}{l}13000- \\
15000\end{array}$ & $\begin{array}{l}14000- \\
29000\end{array}$ & $532-770$ & $17500-19600$ \\
\hline $\mathrm{Na}$ & $240-353$ & & & & & $2.5-9.8$ & $9.6-1467$ \\
\hline $\mathrm{P}$ & $251-342$ & & $2660-3067$ & & & & $1710-2110$ \\
\hline $\mathrm{Mg}$ & $420-500$ & $1800-2000$ & $2145-3067$ & $1500-2000$ & $2000-3100$ & & $2058-2410$ \\
\hline
\end{tabular}


Table 4. Comparison of the results of present study with previous studies for micro elements.

\begin{tabular}{|l|l|l|l|l|}
\hline \multirow{2}{*}{ element } & \multicolumn{4}{|c|}{ Concentration ranges in mg/L } \\
\cline { 2 - 5 } & Present study & Krivan et al. 1993 & Santos et al. 2008 & Sussela et al. 2001 \\
\hline As & $0.05-0.166$ & & $<13$ & \\
\hline $\mathrm{Cr}$ & $0.05-0.3$ & $0.4-1$ & $<0.7$ & $0.7-0.8$ \\
\hline $\mathrm{Ni}$ & $0.016-0.366$ & & $<0.8$ & $0.6-1.9$ \\
\hline $\mathrm{Se}$ & $0.45-0.733$ & & $<5.8$ & \\
\hline $\mathrm{Sn}$ & $0.066-0.15$ & & & \\
\hline
\end{tabular}

Table 5. Comparison of the results of present study with previous studies trace elements.

\begin{tabular}{|c|c|c|c|c|c|c|c|}
\hline \multirow[b]{2}{*}{ element } & \multicolumn{7}{|c|}{ Concentration ranges in $\mathrm{mg} / \mathrm{L}$} \\
\hline & $\begin{array}{l}\text { Present } \\
\text { study }\end{array}$ & $\begin{array}{l}\text { Krivan et } \\
\text { al. } 1993\end{array}$ & $\begin{array}{l}\text { Santos et } \\
\text { al. } 2008\end{array}$ & $\begin{array}{c}\text { Martin et } \\
\text { al. } 1999\end{array}$ & $\begin{array}{c}\text { Sussela et } \\
\text { al. } 2001\end{array}$ & $\begin{array}{l}\text { Tagliaferro } \\
\text { et al. } 2007\end{array}$ & $\begin{array}{l}\text { Anderson } \\
\text { and Smith } \\
2002\end{array}$ \\
\hline $\mathrm{Al}$ & $2.95-4.583$ & & $15.6-262$ & & & & $3-36$ \\
\hline $\mathrm{Ba}$ & $0.933-6.45$ & & $0.754-1.04$ & & & & \\
\hline $\mathrm{Cu}$ & $2.85-3.333$ & $12.1-19.8$ & $13.4-14.2$ & $11.8-17.8$ & $0.4-16$ & & $12.5-18.1$ \\
\hline $\mathrm{Fe}$ & $5.166-8.1$ & $37-57$ & $46.9-94.4$ & $40-73$ & $16-92$ & $129-983$ & $12-31$ \\
\hline $\mathrm{Mn}$ & $\begin{array}{l}7.283- \\
14.617\end{array}$ & $18-56$ & $17.8-19.3$ & $12-45$ & $7-13$ & & $19-39$ \\
\hline $\mathrm{Sr}$ & $\begin{array}{l}9.583- \\
16.783\end{array}$ & $3.2-18$ & $4.51-5.5$ & $4.1-12$ & $1.1-2.6$ & & \\
\hline $\mathrm{Zn}$ & $1.9-3.25$ & $5-7.8$ & $5.27-6.28$ & $4.9-36.9$ & $2.4-8.9$ & 7.4-7.62 & $6.51-8.03$ \\
\hline
\end{tabular}

The chemical composition of the coffee is mostly related to the origin in which the coffee plants grown. The primary factor connected with the elements is the soil conditions, variety of the coffee, and the methods of cultivation of the coffee plants [14]. Procedures included in the green and roasted coffee beans processing or even the methods of the brewing of the coffee are also important [7].

The results showed that there are significant differences between the concentration of ( $\mathrm{Al}, \mathrm{Ba}, \mathrm{K}, \mathrm{Na}, \mathrm{Ni}, \mathrm{Sr}$, and $\mathrm{Zn}$ ) for coffee samples from different origins, highest amount of $\mathrm{Al}$ is exist in $\mathrm{CY}$ and lowest $\mathrm{Al}$ concentration is observed for $\mathrm{CE}$ and $\mathrm{CG}, \mathrm{CC}$ contains highest amount and $\mathrm{CY}$ contains lowest amount of $\mathrm{Ba}$; highest concentration of
$\mathrm{K}$ were observed for $\mathrm{CG}$ but $\mathrm{CK}$ contains lowest amount of $\mathrm{K}$; highest concentration of $\mathrm{Na}$ were observed for $\mathrm{CY}$ and the lowest amount observed for $\mathrm{CE}$; $\mathrm{CC}$ contains highest amount $\mathrm{Sr}$ but lowest amount of $\mathrm{Sr}$ were observed for CB; highest concentration of $\mathrm{Zn}$ were observed for $\mathrm{CK}$ and lowest amount were observed for CE. For elements like (As, Se, Sn, and $\mathrm{Mg}$ ) no significant differences were observed for different coffee samples. For other elements significant difference were observed between the concentrations of only one or two coffee sample with other samples. Figure (2, 3, and 4) shows the differences among the concentration of (macro, micro, and trace) elements in different coffee samples. 


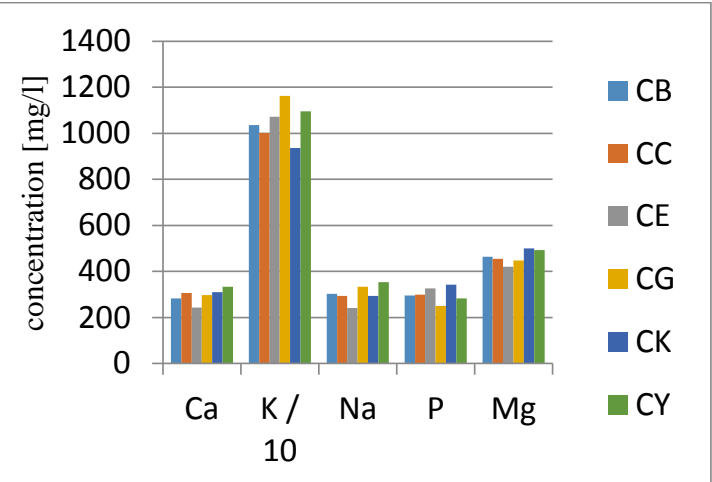

Figure 2. Levels of macro elements in different coffee samples.

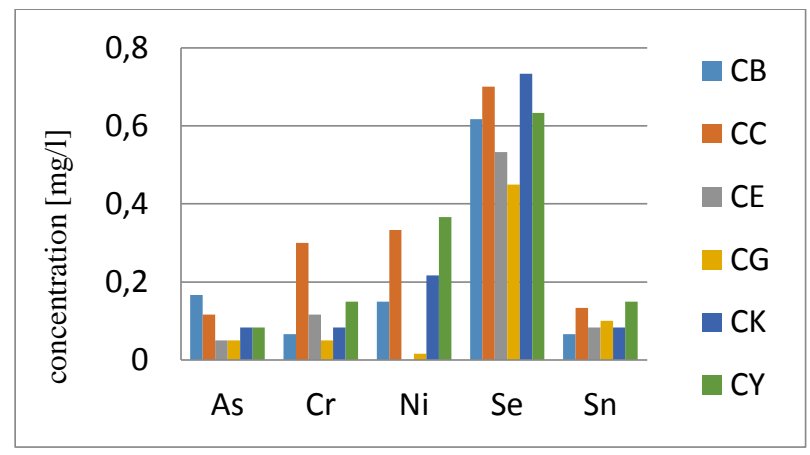

Figure 3. Levels of micro elements in different coffee samples.

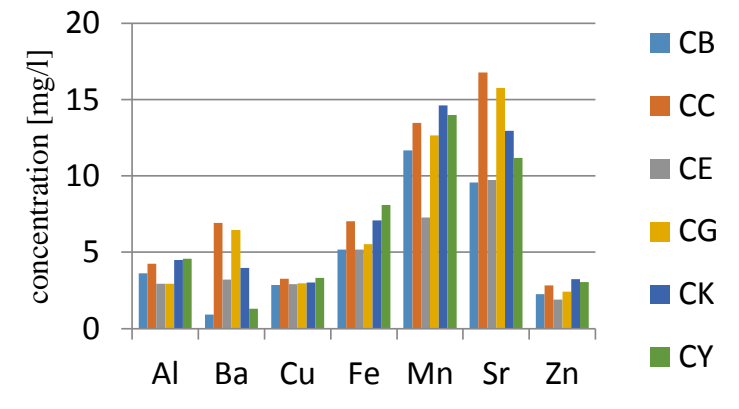

Figure 4. Levels of trace elements in different coffee samples.

\subsection{Comparison with DRI of Elements}

Highest concentration of each element from present study were selected to be compared with dietary reference intakes of the elements when (1 and 3 ) cups of coffee were used for drinking each day if approximately $3 \mathrm{gr}$ of coffee were used for preparing a single cup of coffee, percent daily intake of elements also calculated and the results showed that none of the elements in coffee samples exceeds the maximum daily intake levels even in the case of drinking more than 3 cups of coffee per day, thus all six coffee samples analyzed in present study are safe according to their element content. Dietary reference intake of elements under study, compared with the results obtained in present study are showed in table 6 . 
Table 6. Comparison of the results of present study with dietary reference intake of the elements.

\begin{tabular}{|c|c|c|c|c|c|c|}
\hline \multirow[t]{2}{*}{ Elements } & \multirow{2}{*}{$\begin{array}{l}\text { DRI } \\
\text { (mg/day) } \\
(19-50 \\
\text { years) }\end{array}$} & \multirow{2}{*}{$\begin{array}{l}\text { Concentration } \\
\text { of elements in } \\
\text { coffee } \\
\text { samples } \\
(\mathrm{mg} / \mathrm{L}) \\
\text { (highest } \\
\text { value) }\end{array}$} & \multirow{2}{*}{$\begin{array}{l}\text { Element intake } \\
\text { from one cup } \\
(3 \mathrm{gr}) \text { of coffee } \\
(\mathrm{mg})\end{array}$} & \multirow{2}{*}{$\begin{array}{l}\text { Element intake } \\
\text { from three cups } \\
(9 \mathrm{gr}) \text { of coffee } \\
(\mathrm{mg})\end{array}$} & \multicolumn{2}{|c|}{ Daily Element intake (\%) } \\
\hline & & & & & 1 cup & 3 cups \\
\hline $\mathrm{Al}$ & ND & 4.583 & $0.013749 \mathrm{mg}$ & $0.041247 \mathrm{mg}$ & --- & --- \\
\hline As & ND & 0.166 & $0.000498 \mathrm{mg}$ & $0.001494 \mathrm{mg}$ & --- & --- \\
\hline $\mathrm{Ba}$ & ND & 6.916 & $0.020748 \mathrm{mg}$ & $0.062244 \mathrm{mg}$ & $\overline{---}$ & --- \\
\hline $\mathrm{Ca}$ & $1000-1200$ & 334.73 & $1.00419 \mathrm{mg}$ & $3.01257 \mathrm{mg}$ & $0.083-0.1 \%$ & $0.25-0.30 \%$ \\
\hline $\mathrm{Cr}$ & $0.025-0.035$ & 0.3 & $0.0009 \mathrm{mg}$ & $0.0027 \mathrm{mg}$ & $2.57-3.6 \%$ & $7.71-10.8 \%$ \\
\hline $\mathrm{Cu}$ & $0.89-0.9$ & 3.333 & $0.009999 \mathrm{mg}$ & $0.029997 \mathrm{mg}$ & $1.11-1.12 \%$ & $3.33-3.37 \%$ \\
\hline $\mathrm{Fe}$ & $8-18$ & 8.1 & $0.0243 \mathrm{mg}$ & $0.0729 \mathrm{mg}$ & $0.135-0.3 \%$ & $0.405-0.91 \%$ \\
\hline $\mathrm{K}$ & $4500-4700$ & 11635 & $34.905 \mathrm{mg}$ & $104.715 \mathrm{mg}$ & $0.74-0.77 \%$ & $2.22-2.32 \%$ \\
\hline $\mathrm{Mn}$ & $1.6-2.3$ & 14.616 & $0.043848 \mathrm{mg}$ & $0.131544 \mathrm{mg}$ & $1.9-2.7 \%$ & $5.71-8.22 \%$ \\
\hline $\mathrm{Na}$ & $1300-1500$ & 353.38 & $1.06014 \mathrm{mg}$ & $3.18042 \mathrm{mg}$ & $0.07-0.08 \%$ & $0.21-0.24 \%$ \\
\hline $\mathrm{Ni}$ & $0.6-1$ & 0.366 & $0.001098 \mathrm{mg}$ & $0.003294 \mathrm{mg}$ & $0.109-0.183 \%$ & $0.329-0.549 \%$ \\
\hline $\mathrm{P}$ & $600-700$ & 342.38 & $1.02714 \mathrm{mg}$ & $3.08142 \mathrm{mg}$ & $\begin{array}{l}0.146-0.171 \\
\%\end{array}$ & $0.44-0.51 \%$ \\
\hline $\mathrm{Se}$ & $0.05-0.055$ & 0.733 & $0.002199 \mathrm{mg}$ & $0.006597 \mathrm{mg}$ & $3.99-4.39 \%$ & $11.99-13.19 \%$ \\
\hline Sn & ND & 0.15 & $0.00045 \mathrm{mg}$ & $0.00135 \mathrm{mg}$ & --- & --- \\
\hline $\mathrm{Sr}$ & ND & 16.783 & $0.050349 \mathrm{mg}$ & $0.151047 \mathrm{mg}$ & $\begin{array}{ll}-- \\
\end{array}$ & --- \\
\hline $\mathrm{Zn}$ & $8-11$ & 3.25 & $0.00975 \mathrm{mg}$ & $0.02925 \mathrm{mg}$ & $0.088-0.12 \%$ & $0.26-0.36 \%$ \\
\hline $\mathrm{Mg}$ & $320-420$ & 500.77 & $1.50231 \mathrm{mg}$ & $4.50693 \mathrm{mg}$ & $0.35-0.47 \%$ & $1.07-1.4 \%$ \\
\hline
\end{tabular}

ND: Not Determined, DRI: Dietary Reference Intake

\subsection{Correlation between Elements}

To determine correlation between concentrations of elements in coffee samples, Pearson's correlation coefficient were assessed. As can be seen from table 4 very high positive correlation ( $r>0.9)$ is observed only for $\mathrm{Cu}-\mathrm{Fe}, \mathrm{Ca}-\mathrm{Mn}, \mathrm{Ba}-\mathrm{Sr}$ and $\mathrm{Zn}-\mathrm{Mn}$ pairs of elements. high positive correlations $(0.7<\mathrm{r}>0.9)$ exhibit the following pairs of elements: $\mathrm{Ca}-\mathrm{Al}, \mathrm{Ca}-\mathrm{Cu}, \mathrm{Cr}-\mathrm{Cu}, \mathrm{Al}-$ $\mathrm{Fe}, \mathrm{Fe}-\mathrm{Ca}, \mathrm{Al}-\mathrm{Mn}, \mathrm{Fe}-\mathrm{Mn}, \mathrm{Ni}-\mathrm{Al}, \mathrm{Ni}-\mathrm{Cu}, \mathrm{Ni}-\mathrm{Fe}, \mathrm{Ni}-\mathrm{Mn}$, $\mathrm{Zn}-\mathrm{Al}, \mathrm{Al}-\mathrm{Mg}, \mathrm{Ca}-\mathrm{Zn}, \mathrm{Ca}-\mathrm{Mg}$, Fe-Zn, Fe-Mg, Mn-Mg, $\mathrm{Zn}-\mathrm{Ni}, \mathrm{Zn}-\mathrm{Mg}, \mathrm{Mn}-\mathrm{Na}$ and $\mathrm{Ni}-\mathrm{Ca}$. while high negative correlation exist between $\mathrm{P}-\mathrm{K}$ and Al-Ba. For other pairs of elements, positive or negative correlations are established and they are moderate ( $\mathrm{r}= \pm 0.4$ to \pm 0.7$)$, low ( $r= \pm 0.2$ to \pm 0.4 ) or almost negligible ( $r=0$ to \pm 0.2 ). 


\begin{tabular}{|c|c|c|c|c|c|c|c|c|c|c|c|c|c|c|c|c|}
\hline & Al & As & $\mathbf{B a}$ & $\mathrm{Ca}$ & $\mathrm{Cr}$ & $\mathrm{Cu}$ & $\mathbf{F e}$ & $\mathbf{K}$ & Mn & $\mathbf{N a}$ & $\mathbf{N i}$ & $\mathbf{P}$ & Se & Sn & $\mathrm{Sr}$ & $\mathbf{Z n}$ \\
\hline As & $\begin{array}{l}0.227 \\
0.365\end{array}$ & & & & & & & & & & & & & & & \\
\hline $\mathbf{B a}$ & $\begin{array}{l}- \\
0.716 \\
0.489\end{array}$ & $\begin{array}{c}-0.216 \\
0.388\end{array}$ & & & & & & & & & & & & & & \\
\hline Ca & $\begin{array}{l}0.716 \\
0.001\end{array}$ & $\begin{array}{l}0.073 \\
0.772\end{array}$ & $\begin{array}{l}0.028 \\
0.911\end{array}$ & & & & & & & & & & & & & \\
\hline $\mathrm{Cr}$ & $\begin{array}{l}0.365 \\
0.136\end{array}$ & $\begin{array}{l}-0.044 \\
0.862\end{array}$ & $\begin{array}{l}0.332 \\
0.179\end{array}$ & $\begin{array}{l}0.259 \\
0.299\end{array}$ & & & & & & & & & & & & \\
\hline $\mathbf{C u}$ & $\begin{array}{l}0.615 \\
0.007\end{array}$ & $\begin{array}{r}-0.117 \\
0.643\end{array}$ & $\begin{array}{l}0.141 \\
0.577\end{array}$ & $\begin{array}{l}0.739 \\
0.000\end{array}$ & $\begin{array}{l}0.733 \\
0.001\end{array}$ & & & & & & & & & & & \\
\hline $\mathbf{F e}$ & $\begin{array}{l}0.790 \\
0.000\end{array}$ & $\begin{array}{r}-0.013 \\
0.960\end{array}$ & $\begin{array}{r}-0.010 \\
0.967\end{array}$ & $\begin{array}{l}0.846 \\
0.000\end{array}$ & $\begin{array}{l}0.536 \\
0.022\end{array}$ & $\begin{array}{l}0.901 \\
0.000\end{array}$ & & & & & & & & & & \\
\hline $\mathbf{K}$ & $\begin{array}{l}- \\
0.586 \\
0.011\end{array}$ & $\begin{array}{r}-0.216 \\
0.390\end{array}$ & $\begin{array}{l}0.040 \\
0.875\end{array}$ & $\begin{array}{l}-0.065 \\
0.797\end{array}$ & $\begin{array}{r}-0.225 \\
0.370\end{array}$ & $\begin{array}{l}0.004 \\
0.988\end{array}$ & $\begin{array}{r}-0.224 \\
0.372\end{array}$ & & & & & & & & & \\
\hline Mn & $\begin{array}{l}0.731 \\
0.001\end{array}$ & $\begin{array}{l}0.129 \\
0.610\end{array}$ & $\begin{array}{l}0.165 \\
0.512\end{array}$ & $\begin{array}{l}0.923 \\
0.000\end{array}$ & $\begin{array}{l}0.209 \\
0.406\end{array}$ & $\begin{array}{l}0.562 \\
0.015\end{array}$ & $\begin{array}{l}0.724 \\
0.001\end{array}$ & $\begin{array}{r}-0.265 \\
0.288\end{array}$ & & & & & & & & \\
\hline $\mathbf{N a}$ & $\begin{array}{l}0.375 \\
0.126\end{array}$ & $\begin{array}{l}0.031 \\
0.904\end{array}$ & $\begin{array}{r}-0.079 \\
0.756\end{array}$ & $\begin{array}{l}0.787 \\
0.000\end{array}$ & $\begin{array}{c}-0.096 \\
0.705\end{array}$ & $\begin{array}{l}0.417 \\
0.085\end{array}$ & $\begin{array}{l}0.459 \\
0.055\end{array}$ & $\begin{array}{l}0.378 \\
0.122\end{array}$ & $\begin{array}{l}0.716 \\
0.001\end{array}$ & & & & & & & \\
\hline $\mathbf{N i}$ & $\begin{array}{l}0.867 \\
0.000\end{array}$ & $\begin{array}{l}0.185 \\
0.461\end{array}$ & $\begin{array}{r}-0.111 \\
0.661\end{array}$ & $\begin{array}{l}0.772 \\
0.000\end{array}$ & $\begin{array}{l}0.644 \\
0.004\end{array}$ & $\begin{array}{l}0.811 \\
0.000\end{array}$ & $\begin{array}{l}0.859 \\
0.000\end{array}$ & $\begin{array}{r}-0.385 \\
0.114\end{array}$ & $\begin{array}{l}0.704 \\
0.001\end{array}$ & $\begin{array}{l}0.437 \\
0.070\end{array}$ & & & & & & \\
\hline $\mathbf{P}$ & $\begin{array}{l}0.310 \\
0.211\end{array}$ & $\begin{array}{l}0.040 \\
0.874\end{array}$ & $\begin{array}{c}-0.199 \\
0.428\end{array}$ & $\begin{array}{l}-0.177 \\
0.488\end{array}$ & $\begin{array}{l}0.187 \\
0.459\end{array}$ & $\begin{array}{l}0.002 \\
0.994\end{array}$ & $\begin{array}{l}0.199 \\
0.430\end{array}$ & $\begin{array}{r}-0.767 \\
0.000\end{array}$ & $\begin{array}{r}-0.112 \\
0.657\end{array}$ & $\begin{array}{r}-0.665 \\
0.003\end{array}$ & $\begin{array}{l}0.128 \\
0.613\end{array}$ & & & & & \\
\hline $\mathrm{Se}$ & $\begin{array}{l}0.499 \\
0.035\end{array}$ & $\begin{array}{r}-0.361 \\
0.141\end{array}$ & $\begin{array}{r}-0.071 \\
0.778\end{array}$ & $\begin{array}{l}0.271 \\
0.271\end{array}$ & $\begin{array}{l}0.362 \\
0.140\end{array}$ & $\begin{array}{l}0.283 \\
0.256\end{array}$ & $\begin{array}{l}0.358 \\
0.144\end{array}$ & $\begin{array}{r}-0.592 \\
0.010\end{array}$ & $\begin{array}{l}0.337 \\
0.171\end{array}$ & $\begin{array}{r}-0.014 \\
0.957\end{array}$ & $\begin{array}{l}0.514 \\
0.029\end{array}$ & $\begin{array}{l}0.363 \\
0.139\end{array}$ & & & & \\
\hline Sn & $\begin{array}{l}0.300 \\
0.227\end{array}$ & $\begin{array}{c}-0.016 \\
0.949\end{array}$ & $\begin{array}{l}0.106 \\
0.677\end{array}$ & $\begin{array}{l}0.402 \\
0.098\end{array}$ & $\begin{array}{l}0.393 \\
0.106\end{array}$ & $\begin{array}{l}0.526 \\
0.025\end{array}$ & $\begin{array}{l}0.456 \\
0.057\end{array}$ & $\begin{array}{l}0.146 \\
0.564\end{array}$ & $\begin{array}{l}0.267 \\
0.285\end{array}$ & $\begin{array}{l}0.278 \\
0.264\end{array}$ & $\begin{array}{l}0.411 \\
0.090\end{array}$ & $\begin{array}{r}-0.119 \\
0.638\end{array}$ & $\begin{array}{c}-0.071 \\
0.781\end{array}$ & & & \\
\hline $\mathrm{Sr}$ & $\begin{array}{l}0.107 \\
0.673\end{array}$ & $\begin{array}{r}-0.100 \\
0.964\end{array}$ & $\begin{array}{l}0.918 \\
0.000\end{array}$ & $\begin{array}{l}0.380 \\
0.119\end{array}$ & $\begin{array}{l}0.396 \\
0.104\end{array}$ & $\begin{array}{l}0.361 \\
0.141\end{array}$ & $\begin{array}{l}0.246 \\
0.325\end{array}$ & $\begin{array}{l}0.028 \\
0.912\end{array}$ & $\begin{array}{l}0.504 \\
0.033\end{array}$ & $\begin{array}{l}0.271 \\
0.277\end{array}$ & $\begin{array}{l}0.196 \\
0.435\end{array}$ & $\begin{array}{r}-0.342 \\
0.165\end{array}$ & $\begin{array}{l}0.022 \\
0.930\end{array}$ & $\begin{array}{l}0.241 \\
0.334\end{array}$ & & \\
\hline $\mathbf{Z n}$ & $\begin{array}{l}0.851 \\
0.000\end{array}$ & $\begin{array}{l}0.044 \\
0.861\end{array}$ & $\begin{array}{l}0.084 \\
0.740\end{array}$ & $\begin{array}{l}0.874 \\
0.000\end{array}$ & $\begin{array}{l}0.318 \\
0.198\end{array}$ & $\begin{array}{l}0.667 \\
0.003\end{array}$ & $\begin{array}{l}0.883 \\
0.000\end{array}$ & $\begin{array}{c}-0.432 \\
0.073\end{array}$ & $\begin{array}{l}0.911 \\
0.000\end{array}$ & $\begin{array}{l}0.513 \\
0.029\end{array}$ & $\begin{array}{l}0.777 \\
0.000\end{array}$ & $\begin{array}{l}0.212 \\
0.398\end{array}$ & $\begin{array}{l}0.421 \\
0.082\end{array}$ & $\begin{array}{l}0.313 \\
0.206\end{array}$ & $\begin{array}{l}0.366 \\
0.135\end{array}$ & \\
\hline Mg & $\begin{array}{l}0.736 \\
0.001\end{array}$ & $\begin{array}{l}0.131 \\
0.605\end{array}$ & $\begin{array}{l}-0.249 \\
0.319\end{array}$ & $\begin{array}{l}0.832 \\
0.000\end{array}$ & $\begin{array}{l}0.135 \\
0.593\end{array}$ & $\begin{array}{l}0.558 \\
0.016\end{array}$ & $\begin{array}{l}0.801 \\
0.000\end{array}$ & $\begin{array}{r}-0.330 \\
0.182\end{array}$ & $\begin{array}{l}0.813 \\
0.000\end{array}$ & $\begin{array}{l}0.505 \\
0.033\end{array}$ & $\begin{array}{l}0.669 \\
0.002\end{array}$ & $\begin{array}{l}0.270 \\
0.278\end{array}$ & $\begin{array}{l}0.340 \\
0.168\end{array}$ & $\begin{array}{l}0.218 \\
0.384\end{array}$ & $\begin{array}{l}0.028 \\
0.912\end{array}$ & $\begin{array}{l}0.874 \\
0.000\end{array}$ \\
\hline
\end{tabular}

Table 4. Correlations between the elements according to Pearson's correlation coefficient. 


\section{Conclusion}

Coffee is one of the most widely consumed beverages throughout the world. In this six coffee samples from different origins were analyzed for determination of 17 inorganic elements. Concentration of elements were determined by using inductively coupled plasma optical emission spectroscopy (ICP-OES), sample preparation procedure based on the partial decomposition in aquaregia is simple, safe, reproducible, and reliable for the determination of total concentrations of $\mathrm{As}, \mathrm{Ba}, \mathrm{Ca}, \mathrm{Cr}, \mathrm{Cu}$, $\mathrm{Fe}, \mathrm{K}, \mathrm{Mn}, \mathrm{Na}, \mathrm{Ni}, \mathrm{P}, \mathrm{Se}, \mathrm{Sn}, \mathrm{Sr}, \mathrm{Zn}$, and $\mathrm{Mg}$. in addition, the use of aquaregia improves the sample solubilisation, reduces the reagents consumption and the time of analysis.

The results obtained in this study showed there are significant differences between different elemental content of different coffee samples grown in different region, for most of the elements determined especially macro and micro elements coffee beans from Yemen (CY) and Kenya (CK) have higher concentration than other samples, except for the elements like $\mathrm{Ba}$ and $\mathrm{Sr}$ in which Colombian coffee beans (CC) contain highest amount and $\mathrm{K}$ and As in which coffee beans from Guatemala (CG) and Brazil (CB) contain higher amount of these two elements respectively. The element content of all coffee samples in present study were lower than dietary reference intake of the elements, thus all coffee samples are safe for daily usage.

\section{Author's Contributions}

Sabah H. Al-Jaf: Drafted and wrote the manuscript, performed the experiment and result analysis.

Sinan Saydam: Assisted in analytical analysis on the structure, supervised the experiment's progress, result interpretation and helped in manuscript preparation.

\section{Ethics}

There are no ethical issues after the publication of this manuscript.

\section{References}

1. Parras, P, M, Martínez-Tomé, A, M, Jiménez, and M, A, Murcia. 2007. Antioxidant capacity of coffees of several origins brewed following three different procedures. Food chemistry; 102(3): 582-592

2. Dos Santos, Éder José, and Elisabeth de Oliveira. 2001. Determination of mineral nutrients and toxic elements in Brazilian soluble coffee by ICPAES. Journal of Food Composition and Analysis; 14(5): 523-531.

3. P, S, Murty, M, M, Naidu. 2012. Sustainable management of coffee industry by-products and value addition-A review. Resources, Conservation and recycling; 66: 45-58.

4. M, Oliveira, S, Casal, S, Morais, C, Alves, F, Dias, S, Ramos, E, Mendes, C, Delerue-Matos, and B, P, P, Oliveira. 2012. Intra-and interspecific mineral composition variability of commercial instant coffees and coffee substitutes: Contribution to mineral intake. Food Chemistry: 130(3): 702-709.
5. M, S, Butt, M, T, Sultan. 2011. Coffee and its consumption: benefits and risks. Critical reviews in food science and nutrition; 51(4): 363-373.

6. Ashu, Ramato, and Bhagwan Singh Chandravanshi. 2011. Concentration levels of metals in commercially available Ethiopian roasted coffee powders and their infusions. Bulletin of the Chemical Society of Ethiopia; 25(1): 11-24.

7. Grembecka, Małgorzata, Ewa Malinowska, and Piotr Szefer. 2007. Differentiation of market coffee and its infusions in view of their mineral composition. Science of the Total Environment; 383(1): 59-69.

8. Esquivel, Patricia, and Víctor M. Jiménez. 2012. Functional properties of coffee and coffee by-products. Food Research International; 46(2): 488495.

9. G, W, Naakubuza, M, A, Bekunda, S, Lwasa, R, Birabwa and S, Muwanga. 2005. Determining the limiting nutrients in coffee plantations at Makerere University Agricultural Reseach Institute. African Crop Science Conference Proceedings; 7: 1085-1088.

10. C, S, F, Gomes, J, B, P, Silva. 2007. Minerals and clay minerals in medical geology. Applied Clay Science; 36(1): 4-21.

11. Stelmach, Ewelina, Pawel Pohl, and Anna Szymczycha-Madeja. 2015. The content of $\mathrm{Ca}, \mathrm{Cu}, \mathrm{Fe}, \mathrm{Mg}$ and $\mathrm{Mn}$ and antioxidant activity of green coffee brews. Food chemistry; 182: 302-308.

12. Derun, E, M, Kipcak, A, S, Ozdemir, O, D, \& Piskin, M, B. 2012. Cr, Fe and Se Contents of the Turkish Black and Green Teas and the Effect of Lemon Addition. World Academy of Science, Engineering and Technology, International Journal of Biological, Biomolecular, Agricultural, Food and Biotechnological Engineering; 6(11): 1018-1022.

13. Krivan, Viliam, Peter Barth, and Alejandro Feria Morales. 1993. Multielement analysis of green coffee and its possible use for the determination of origin. Microchimica Acta; 110(4-6): 217-236.

14. Anderson, Kim, A, and Brian, W, Smith. 2002. Chemical profiling to differentiate geographic growing origins of coffee. Journal of Agricultural and Food Chemistry; 50(7): 2068-2075.

15. Ozdestan. 2014. Evaluation of bioactive amine and mineral levels in Turkish coffee. Food research international; 61: 167-175.

16. Szymczycha-Madeja, Anna, Maja Welna, and Pawel Pohl. 2014. Fast method of elements determination in slim coffees by ICP OES. Food chemistry; 146: 220-225.

17. Santos, W, P, C, Vanessa Hatje, L, N, Lima, S, V, Trignano, F, Barros, J, T, Castro, and Maria das Graças Andrade Korn. 2008. Evaluation of sample preparation (grinding and sieving) of bivalves, coffee and cowpea beans for multi-element analysis. Microchemical Journal; 89(2): 123-130.

18. Martın, M, J, F, Pablos, and A, G, González. 1999. Characterization of arabica and robusta roasted coffee varieties and mixture resolution according to their metal content. Food chemistry; 66(3): 365-370.

19. Tagliaferro, F, E, De Nadai Fernandes, M, Bacchi, P, Bode, and E, Joacir De França. 2006. Can impurities from soil-contaminated coffees reach the cup. Journal of radioanalytical and nuclear chemistry; 271(2): 371-375.

20. Suseela, B, S, Bhalke, and A, Vinod Kumar. 2001. Daily intake of trace metals through coffee consumption in India. Food Additives \& Contaminants; 18(2): 115-120. 